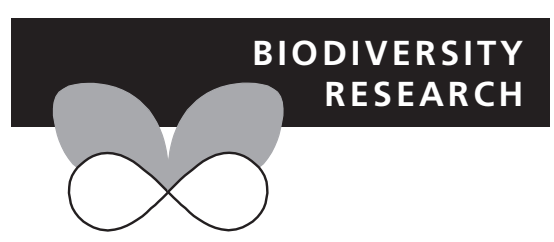

\title{
Reconstructing plant invasions using historical aerial imagery and pollen core analysis: Typha in the Laurentian Great Lakes
}

\author{
Shane C. Lishawa ${ }^{1,2} *$, David. J. Treering ${ }^{1}$, Lane M. Vail ${ }^{1}$, Owen McKenna ${ }^{1}$, \\ Eric C. Grimm ${ }^{3}$ and Nancy C. Tuchman ${ }^{1,2}$
}

${ }^{1}$ Center for Urban Environmental Research and Policy and the Department of Biology, Loyola University Chicago, Chicago, IL, 60626, USA, ${ }^{2}$ University of Michigan Biological Station, 9133 Biological Rd., Pellston, MI, 96067, USA, ${ }^{3}$ Illinois State Museum, Research and Collections Center, 1011 East Ash Street, Springfield, IL, 62703, USA

*Corresponding: Shane C. Lishawa, Center for Urban Environmental Research and Policy and the Department of Biology, Loyola University Chicago, Chicago, IL 60626, USA. E-mail: slishawa@luc.edu

\begin{abstract}
Aim Determining the spatial-temporal spread of an invasive plant is vital for understanding long-term impacts. However, invasions have rarely been directly documented given the resources required and the need for substantial foresight. One method widely used is historical photography interpretation, but this can be hard to verify. We attempt to improve this method by linking historical aerial photos to a paleobotanical analysis of pollen cores.
\end{abstract}

Location Laurentian Great Lakes coastal wetlands, United States of America.

Methods We chose invasive cattail (Typha) as our model species because it is identifiable from aerial imagery and has persistent, identifiable pollen, and its ecological impacts appear to be time-dependent. We used Geographic Information Systems, aerial photo-interpretation and field verification to post-dict the invasion history of Typha in several wetland ecosystems. Using ${ }^{210} \mathrm{~Pb}$ and ${ }^{137} \mathrm{Cs}$ sediment dating and pollen classification, we correlated the temporal dominance of Typha to our estimates of per cent coverage at one site. The pollen record was then used to estimate the Typha invasion dynamics for dates earlier than those for which aerial photos were available.

Results Typha spread through time in all study wetlands. Typha pollen dominance increased through time corresponding with increased spatial dominance. Hybrid cattail, T. $\times$ glauca increased in pollen abundance relative to T. angustifolia pollen through time.

Main conclusions This study illustrates the value of generating historical invasion maps with publically available aerial imagery and linking these maps with paleobotanical data to study recent $(<100$ years $)$ invasions. We determined rates of Typha expansion in two coastal wetland types, validated our mapping methods and modelled the relationship between pollen abundance and wetland coverage, enhancing the temporal precision and breadth of analyses. Our methodology should be replicable with similar invasive plant species. The combination of pollen records and historical photography promises to be a valuable additional tool for determining invasion dynamics.

\section{Keywords}

Aerial imagery, biological invasions, invasive species, long-term effects, pollen core analyses, Typha. 


\section{INTRODUCTION}

The ecological effects of invasive species tend to vary temporally (Witkowski \& Wilson, 2001; Lovett et al., 2006; Marchante et al., 2008; Carlsson et al., 2010), as the invading species, the invaded biological community, abiotic ecosystem components and invader-ecosystem interactions undergo dynamic nonlinear changes through time (Strayer et al., 2006). Thus, the importance of considering temporal context in invasive species research is increasingly recognized (Blossey, 1999; Strayer et al., 2006). Understanding the long-term effects of invasive species would ideally be accomplished by studying a specific ecosystem pre- and post-invasion. However, this approach is seldom possible as pre-invasion data collection is rare, obtaining funding for long-term ecological research is difficult (Callahan, 1984; Hobbie et al., 2003), and the time frame necessary to study long-term invasion processes is often too great (but, see Meiners et al., 2001, 2002; Carlsson et al., 2010). Different approaches are thus necessary to study invasive species in a temporal context. A chronosequence approach, which has been successfully used to study plant succession (e.g. Foster \& Tilman, 2000), is a pragmatic alternative to study the ecological effects of plant invasions through time (Witkowski \& Wilson, 2001; Zavaleta \& Kettley, 2006; Springsteen et al., 2010).

Establishing an invasion chronosequence requires an accurate spatial-historical reconstruction of the spread of the invasive species, which can be accomplished using remotely sensed data analysed with Geographic Information Systems (GIS) technology. Hyperspectral aerial imagery has been utilized effectively to detect, map and model invasive plant species in the landscape (Underwood et al., 2003; Hestir et al., 2008; He et al., 2011), yet its high cost and the lack of historical imagery makes chronosequence development unfeasible (Jensen et al., 1984, 1986; Underwood et al., 2003). In contrast, historical aerial imagery is widely available, free or inexpensive, and in the United States, temporal coverage extends from the late 1930s through the present (USGS, 2010). However, the resolution of aerial photography is limited and may not allow for accurate species-specific spectral signature identification (Huang \& Asner, 2009). Despite limitations, when used in concert with ancillary geospatial data, field demarcation, and ground-truthing for accuracy and precision improvements, historical aerial imagery may be utilized to accurately determine the spatial extent of target plant species at various points in time (Robbins, 1997; Zavaleta \& Kettley, 2006; Boers \& Zedler, 2008; Wilcox et al., 2008). However, because traditional ground-truthing can only be directly applied to the most recent image, errors are likely to occur in historical interpretation, and alternative methods are necessary for accuracy validation.

Paleobotanical data could be used to evaluate historical image interpretation accuracy and enhance analyses of invasion dynamics. Fossil-pollen data reflect relative vegetation abundance at the time of deposition and can illustrate plant community shifts over time (Moore, 1991) and could provide the historical data necessary to evaluate photo-interpretation accuracy. Paleoecological studies typically examine changes in vegetation at the centennial or millennial timescales (Bunting et al., 1997; Finkelstein \& Davis, 2006). However, ${ }^{210} \mathrm{~Pb}$ and ${ }^{137} \mathrm{Cs}$ sediment dating and pollen core analysis together can be used to identify more recent vegetation shifts (50-100 yr BP) (Goldberg, 1963; Jackson, 1997). Although numerous studies have combined remote sensing analyses and paleoecological analyses to model vegetation at a landscape scale (e.g. Broström et al., 1998; Williams \& Jackson, 2003; McLauchlan et al., 2007), no known studies have applied the novel approach of linking site-specific aerial photography interpretation and palynology to examine invasion dynamics.

\section{Invasive Typha spp. in Great Lakes wetlands}

Invasive Typha spp. are appropriate model species for chronosequence development and paleo-dating because of their invasion dynamics, ecological impacts, physical structure, and persistent and readily identifiable wind-distributed pollen. In the Laurentian Great Lakes region, the invasive narrow-leaved cattail (Typha angustifolia L.) and hybrid cattail (Typha $\times$ glauca Godr.), a hybrid between native T. latifolia L. and T. angustifolia (Smith, 1987), are dominant and ecologically disruptive species (Mills et al., 1993; Galatowitsch et al., 1999). Recent genetic analyses has revealed that in the upper Great Lakes region, in sites where both parent species are present, $F_{1}$ hybrids tend to dominate, but backcrossing and advanced generation hybrids also occur (Snow et al., 2010; Travis et al., 2010). Additionally, T. angustifolia and T. $\times$ glauca are structurally similar, making differentiation from aerial imagery difficult. Because of physical similarities, habitat overlap, and similarities in invasion dynamics, invasive Typha spp. are commonly undifferentiated in the ecological literature (e.g. Frieswyk \& Zedler, 2007; Trebitz \& Taylor, 2007; Tulbure et al., 2007; Chun \& Choi, 2009; Vaccaro et al., 2009; Mitchell et al., 2011). Therefore, in this study, we considered both $T$. angustifolia and $T . \times$ glauca as 'invasive Typha'.

Invasive Typha has become abundant in Great Lakes regional wetlands (Mills et al., 1993; Trebitz \& Taylor, 2007) because of increased propagule pressure (Zedler \& Kercher, 2004; Lockwood et al., 2005), alterations in hydrology (McDonald, 1955; Wilcox et al., 1985; Shay \& Shay, 1986; Wilcox \& Nichols, 2008; Wilcox et al., 2008; Farrell et al., 2010) and anthropogenic nutrient enrichment (Crosbie \& Chow-Fraser, 1999; Trebitz et al., 2007; Trebitz \& Taylor, 2007; Morrice et al., 2008). Typha tolerates a wide range of water levels (Harris \& Marshall, 1963; Waters \& Shay, 1990), and recent historically low water levels have been linked to invasions into Lake Michigan and Lake Huron coastal wetlands (Frieswyk \& Zedler, 2007; Tulbure et al., 2007; Lishawa et al., 2010). Climate change is predicted to further reduce water levels over the next 50-100 years (Mortsch \& Quinn, 1996; Lofgren et al., 2002; Angel \& Kunkel, 2009), likely 
increasing Typha dominance (Lishawa et al., 2010). Following establishment, Typha can spread rapidly (Tulbure et al., 2007; Boers \& Zedler, 2008) and is typically much larger than the native species it replaces (Woo \& Zedler, 2002). Because of high rates of primary productivity and slow decomposition (Davis \& Van der Valk, 1978; Freyman, 2008), litter accumulates in Typha beds (Vaccaro et al., 2009) eventually excluding other macrophytes (Larkin et al., 2012). In Great Lakes coastal wetlands, T. $\times$ glauca dominance reduces plant community diversity (Tuchman et al., 2009; Lishawa et al., 2010) and sediments in T. $\times$ glauca stands tend to have unique physical composition, microbial communities (Angeloni et al., 2006) and elevated nutrient concentrations (Tuchman et al., 2009; Farrer \& Goldberg, 2009; Lishawa et al., 2010). Typha's great biomass and persistent litter give Typha stands novel structure, allowing for remote sensing demarcation. Historical aerial and satellite imagery have been used successfully to assess Typha spread rates (Boers \& Zedler, 2008) and increased dominance through time (Wilcox et al., 2008; Farrell et al., 2010). Invasive Typha are also appropriate species for paleoecological analyses because they have distinct and persistent pollen. Typha latifolia produces tetrad pollen grains, whereas T. angustifolia produces monads and hybrid $T . \times$ glauca produces monads, dyads, triads and tetrads. Thus, presence of dyads and triads is indicative of $T . \times$ glauca (Finkelstein, 2003), and the ratio of pollen types indicates relative dominance of Typha species. Furthermore, Typha pollen is widely wind-dispersed and persists as a significant extralocal component of the pollen record (Janssen, 1984; Clark \& Patterson, 1985; Finkelstein \& Davis, 2005), allowing for wetland-scale interpretation of Typha dominance from a single pollen core.

Our goals were to develop replicable methods for accurately reconstructing the spatial-temporal spread of dominant invasive plant species and link aerial photo-interpretation with paleobotanical analyses. First, we mapped invasive Typha's distribution through time in two Great Lakes coastal wetlands to create an invasion chronosequence. Second, we validated our interpretation with paleobotanical sediment core data and explored invasion dynamics with spatial and paleo-data. The results of this research will be used to examine the effects of invasive species residence time on wetland ecosystem structure and function (e.g. Mitchell et al., 2011) and the effectiveness of Typha management treatments.

\section{METHODS}

\section{Study area}

We selected a northern and southern Great Lakes coastal wetland with old, extensive stands of Typha to conduct our research. The northern study site, Cheboygan Marsh, is a Lake Huron lacustrine, open-embayment wetland (Albert et al., 2005) in northern lower Michigan (Fig. 1). The upland portion of the wetland is dominated by a large stand of T. $\times$ glauca, comprising more than $99 \%$ of the relative bio- mass in the invaded areas (Angeloni et al., 2006; Tuchman et al., 2009). On the lake fringe of the wetland, an emergentmarsh zone approximately $50-\mathrm{m}$ wide is dominated by Juncus, Eleocharis, Carex, Schoenoplectus species and T. angustifolia. The southern study site, Illinois Beach wetlands, is a barrier ridge and swale complex (Albert et al., 2005) located along the south-western Lake Michigan shoreline at the IllinoisWisconsin border (Fig. 1). This site contains three contiguous park and preserve land parcels: Chiwaukee Prairie Preserve, the largest intact coastal wetland complex in southern Wisconsin (Epstein et al., 2002); Spring Bluff Nature Preserve; and Illinois Beach State Park; together, the only remaining undeveloped Great Lakes ridge and swale complex in Illinois. A patchwork of Typha stands, and native wet meadow and emergent-marsh plant communities characterize the swales.

\section{Aerial photo-interpretation}

We implemented five steps to develop the invasion chronosequence that are detailed below.

\section{Imagery acquisition}

We conducted a survey of historical aerial imagery from national, state, county, university and private data sources with the goal of creating a collection of at least one usable image per site for each decade from 1950 through 2009. The United States Department of Agriculture (USDA), Farm Service Administration (FSA), Aerial Photography Field Office distributes 1-2 m resolution, leaf-on condition images as county-wide mosaics. FSA aerial imagery from 2007 to 2009 was available for all study sites from the USDA, Natural Resources Conservation Service's Geospatial Data Gateway (USDA, 2009). We collected historical aerial imagery from the State of Wisconsin, State of Illinois, and State of Michigan websites and through data sharing agreements with Cheboygan County, Michigan and Lake County, Illinois. We surveyed publicly available imagery from Google (Google Inc., Mountain View, CA, USA) and Microsoft (Microsoft Inc., Redmond, CA, USA); both companies provide web-based and desktop applications that include dated high-resolution imagery. Bing Maps ${ }^{\mathrm{TM}}$ (Microsoft Inc., Redmond, CA, USA) houses high resolution (under $1 \mathrm{~m}$ at nadir), low oblique aerial imagery, which were available for the Illinois Beach site. We also obtained historical imagery (1939-2005) from the United States National Archives aerial photography collection (USNARA, 2009), Michigan State University's Aerial Imagery Archive (Michigan State University, 2008) and the USGS Earth Explorer (USGS, 2009). Available imagery occurred in varied formats, including scanned black-andwhite photographs, scanned colour-infrared photographs, scanned colour photographs and digital orthoimagery. After evaluating the spatial, spectral and temporal resolution of the available imagery, we downloaded or purchased at least one photo-interpretable image per decade. Additionally, we 


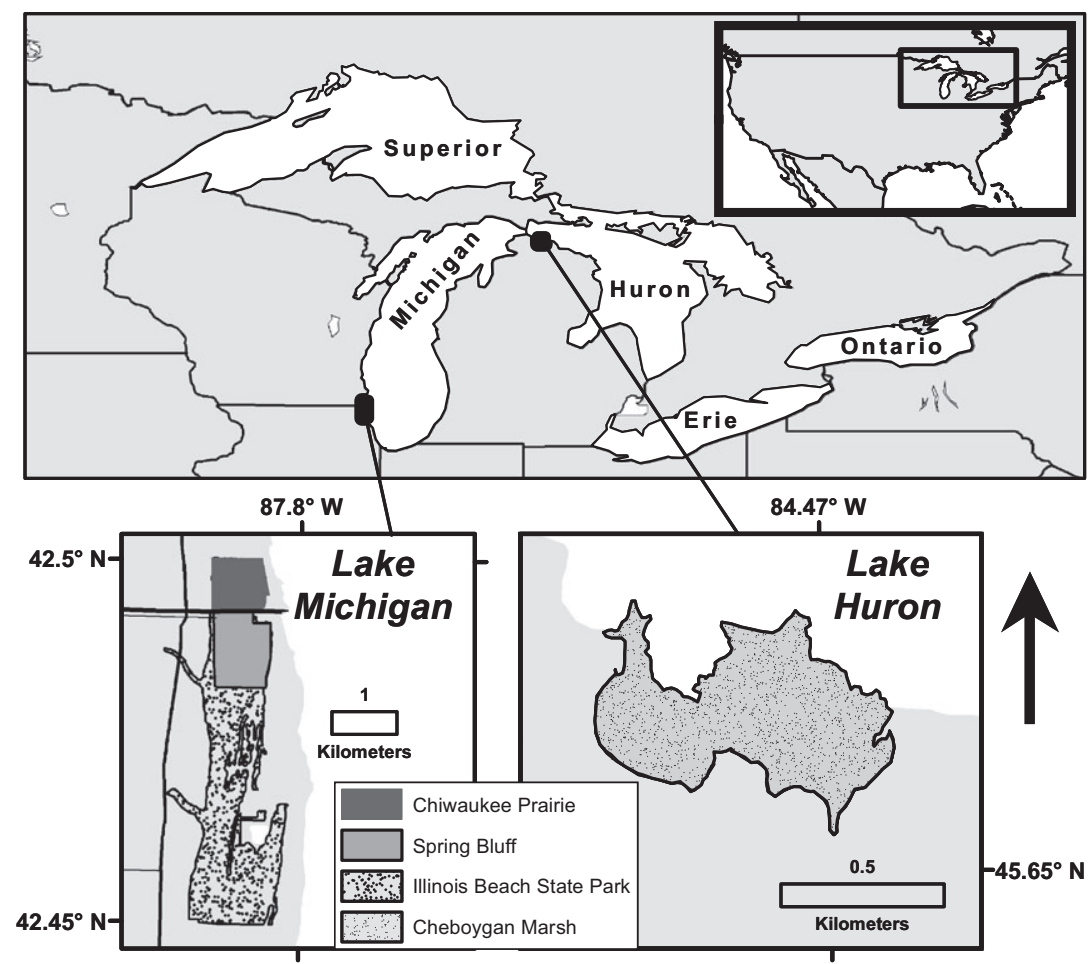

Figure 1 Map of the Illinois Beach and Cheboygan Marsh study wetlands.

collected a wide range of publicly available ancillary geospatial data to support the image classification including digital elevation models, elevation contours, land use and land cover classifications, soils and surface geology classifications, Great Lakes water levels (USACE, 2010), vegetation survey data and ecological management data.

All imagery and ancillary spatial data were imported to a GIS, ARCGIS 9.3 (Environmental Systems Research Institute, Redlands, CA, USA) and standardized prior to interpretation. The georeferencing tool in ARCMAP (Environmental Systems Research Institute, Redlands, CA, USA) was used to georeference images to the base map, as is commonly necessary with scanned photographs, by correlating three or more objects from each image with the same object in a spatially referenced image. Additionally, images were manipulated in ARCMAP to enhance contrast or balance colours. Histogram stretches were applied to many of the images to increase contrast. Choices of spectral bands were limited, as most historical imagery was scanned from black-and-white film, resulting in a single panchromatic spectral band. Original band assignments were used for natural colour or falsecolour-infrared images that contained multiple spectral bands.

\section{Field mapping and digitization of Typha stands}

We determined the current extent of Typha in a portion of each study wetland by collecting field vegetation data. Handheld mapping GPS units (Garmin GPSMAP 60Cx Global Positioning System; Garmin International Inc., Olathe, KS, USA) were used to collect a series of points around the perimeter of contiguous stands of Typha. Stand boundaries were demarcated by determining where Typha litter and living biomass had more than $50 \%$ of aerial coverage. Field teams repeatedly calibrated their assessment to ensure compatibility of data sets and replicability of results. GPS data were loaded into ARCGIS and overlaid on the most recent imagery (2007-2009) base map. A new, empty polygon shapefile was created, and features were added through onscreen digitizing, tracing the sequence of points. Because some stands had convoluted shapes, points were labelled with sequential numbers during data collection to ensure the correct succession when digitizing.

\section{Photo-interpretation}

Traditional manual photo-interpretation techniques (Lillesand et al., 2008) were used to identify discrete Typha polygons. The most recent imagery was overlaid with the Typha polygons, and the characteristics of Typha stands were examined carefully at a range of scales for their shape, size, hue and texture. This detailed assessment revealed that Typha stand texture is homogeneously flat with some striations, whereas the surrounding vegetation (dominated by Carex spp., Schoenoplectus spp., and Juncus spp.) is more heterogeneous in texture (see Fig. S1 in Supporting Information). Following Typha characterization, we manually digitized new Typha polygons outside of the field surveyed area where the majority of the ground cover shared Typha visual characteristics. Ancillary data such as soil type and topography were used in conjunction with the above layers to corroborate 
Typha presence and to refine Typha polygons. When available, vegetation surveys and management practice history data were utilized to further refine image interpretation. In locations where data were available, current high resolution, low oblique aerial imagery (Bing $\mathrm{Maps}^{\mathrm{TM}}$ ) was referenced to further improve interpretation.

\section{Accuracy assessment and interpretation refinement}

An accuracy assessment was conducted to find errors and improve interpretation of Typha delineation. Interpretation confidence levels for each Typha polygon were classified: a value of 1 was given to areas where the interpreter was highly confident that the vegetation was Typha; a value of 2 represented moderate confidence; and a value of 3 represented low confidence and was assigned to polygons with some variability in texture or colour. Randomly located points (RLPs) were generated within all polygons using the 'Generate Random Points' tool in ET Geo Wizards (Tchoukanski, 2008) within ARCMAP. A stratified random sample of RLPs from each confidence category was selected for field ground-truthing. Twenty-five per cent of the RLPs from each confidence category were loaded onto a hand-held GPS unit and visited in the field. A one-metre square vegetation plot was established at each point, and Typha presence or absence, per cent cover, and stem density were recorded.

The accuracy of interpretation was assessed for each confidence category and for each site. For instance, in Spring Bluff, overall interpretation accuracy was $84 \%$; interpretation was $100 \%$ accurate for the highest-confidence category, $85 \%$ accurate for the moderate category and $67 \%$ accurate for the low-confidence category. Using information gained from the accuracy assessment, particularly incorrectly assigned Typha stands, polygon delineations were refined and manual interpretation of digital images was improved through examination of subtle differences in colour and texture between Typha and native vegetation types.

\section{Historical imagery Typha delineation}

Typha is actively expanding its range in our study wetlands (Debbie Maurer, personal communication; Tuchman et al., 2009). Therefore, historical stand extents were typically smaller in each subsequently older image and, with few exceptions, older Typha stands lay entirely within the more modern Typha polygons. Working counter-chronologically from current imagery, the next most recent images were analysed first. Current Typha polygons were overlaid to help facilitate the determination of historical Typha presence. The interpreter manually digitized the reduced perimeter of contiguous stands of Typha within each historical image in succession, creating year-specific Typha extent polygons. Again, differences in texture and colour, as compared to the surrounding ground cover, allowed for delineation. These characteristics differed somewhat between image dates because of variability in image seasonality, sun angles, atmospheric con- ditions and other image distortion. As successively older images were examined, interpretation was recalibrated in the light of variability in image quality.

\section{Paleobotanical analyses}

\section{Sediment dating}

Sediment cores were collected from Cheboygan Marsh in August 2006 (core A, $32 \mathrm{~cm}$ ) and in August 2007 (core B, $40 \mathrm{~cm}$ ) for paleobotanical analyses. Paleobotanical analyses were limited to a single site because of limited available funds. Both cores were collected from within large stands of Typha, proximal to the oldest stands in Cheboygan Marsh and well within the pollen source area where wind-dispersed Typha pollen would be deposited (Janssen, 1984), and which likely experienced similar invasion history because they shared similar sediment profile structure and were equidistant from the Typha invasion edge (approximately $75 \mathrm{~m}$ ). Core $\mathrm{A}$ was used for ${ }^{210} \mathrm{~Pb}$ and ${ }^{137} \mathrm{Cs}$ dating. To reduce analytical costs, four-centimetre subsections of the core were homogenized, dried at $105{ }^{\circ} \mathrm{C}$ for $48 \mathrm{~h}$ and sent to MicroAnalytica LLC for radiometric dating analysis of ${ }^{210} \mathrm{~Pb}$ and ${ }^{137} \mathrm{Cs}$. Assuming a constant flux of unsupported ${ }^{210} \mathrm{~Pb}$ from the atmosphere (Appleby \& Oldfield, 1978), ${ }^{210} \mathrm{~Pb}$ values from each subsection of the core were used to determine a constant flux: constant sedimentation rate (CF:CS; Robbins, 1978). The CF:CS was used to calculate a dry-mass sedimentation rate. Additionally, the depth of the core subsection which contained a peak of ${ }^{137} \mathrm{Cs}$, from nuclear testing in 1963 (Ritchie \& McHenry, 1990), was determined for ${ }^{210} \mathrm{~Pb}$ sediment accumulation rate validation.

\section{Sediment characterization and pollen analyses}

Sediment core B was used to analyse organic-matter content and for pollen analyses; subsamples were taken at $1-\mathrm{cm}$ intervals throughout the length of the core, dried at $105^{\circ} \mathrm{C}$ for $24 \mathrm{~h}$, weighed, then placed in a muffle furnace at $550{ }^{\circ} \mathrm{C}$ for $2 \mathrm{~h}$ (APHA, 2005). The non-volatile ash remaining was subtracted from the initial dry mass, and organic matter was calculated as per cent of dry mass (APHA, 2005).

Preparation of pollen samples followed standard methods (Fægri \& Iversen, 1989), with successive treatments of $10 \%$ $\mathrm{KOH}$ to remove humates, $10 \% \mathrm{HCl}$ to remove carbonates, $49 \% \mathrm{HF}$ to remove silicates and acetolysis solution to remove cellulose. Samples were sieved with a $7-\mu \mathrm{m}$ Nitex screen to remove clay and other fine particles (Cwynar et al., 1979). After dehydration with tert-Butanol, samples were mounted in silicone oil. A spike of $0.5 \mathrm{ml}$ of a suspension of polystyrene microspheres $(15 \mu \mathrm{m})$ of known concentration was added to each volumetric pollen sample, and these were counted along with pollen to calculate pollen concentration. A minimum of 300 pollen grains per sample were counted under $400 \times$ magnification (Moore, 1991). In each sample, the four types of Typha pollen grains (monads, dyads, triads 
and tetrads), native sedge pollen (Cyperaceae) and pine (Pinus) pollen, were counted; pollen grains from other species were identified as other. Pure T. $\times$ glauca pollen has an average of $20 \%$ dyad/triad pollen, whereas pure T. angustifolia pollen has approximately $1 \%$ dyad and $0 \%$ triad, and T. latifolia has $0 \%$ dyad/triad pollen types (Finkelstein, 2003). Therefore, for each pollen sediment section, we calculated the estimated per cent of Typha pollen, that is, T. $\times$ glauca pollen by determining the proportion of dyad/ triad pollen types divided by $20, \pm 5 \%$ (representing up to $5 \%$ dyad contribution from T. angustifolia): T. $\times$ glauca $( \pm 5 \%)=[($ dyad + triad $) / 20]$.

\section{Statistical analyses}

We performed ordinary least-squared linear regression analysis of sediment depth and ${ }^{210} \mathrm{~Pb}$ dating derived ages to determine sediment accretion rates, and we extrapolated continuous sediment profile age estimates between sampled mid-points using the resulting regression function. We evaluated correlations between Cheboygan Marsh Typha pollen abundance and sediment organic matter using a generalized linear model (GLM) with binomial error distribution (Typha pollen abundance $\% \sim$ sediment organic matter\%). Additionally, for those years when aerial photo-interpretation Typha coverage data were generated, we evaluated the relationship between Cheboygan marsh dominance by Typha and Typha pollen abundance using a GLM (Cheboygan Marsh Typha cover (ha) Typha pollen abundance\%); the resulting model was used to post-dict Typha marsh dominance values at the temporal resolution of pollen core samples. To relate Typha pollen abundance data and aerial imagery, which did not always occur from the same years, we assumed a linear change in Typha pollen data between data points and used average values for those years when dates did not align. All statistical analyses were conducted using R 2.12.1 (R Development Core Team, 2010).

\section{RESULTS}

\section{Aerial photography interpretation}

Photo-interpretation and GIS-based delimiting allowed for the spatial reconstruction of the spread of Typha through time and the creation of mapped mosaics representing the age of Typha stands (Figs 2 and 3). Additionally, photointerpretation revealed detailed quantifiable patterns of Typha establishment and invasion in our two study wetlands.

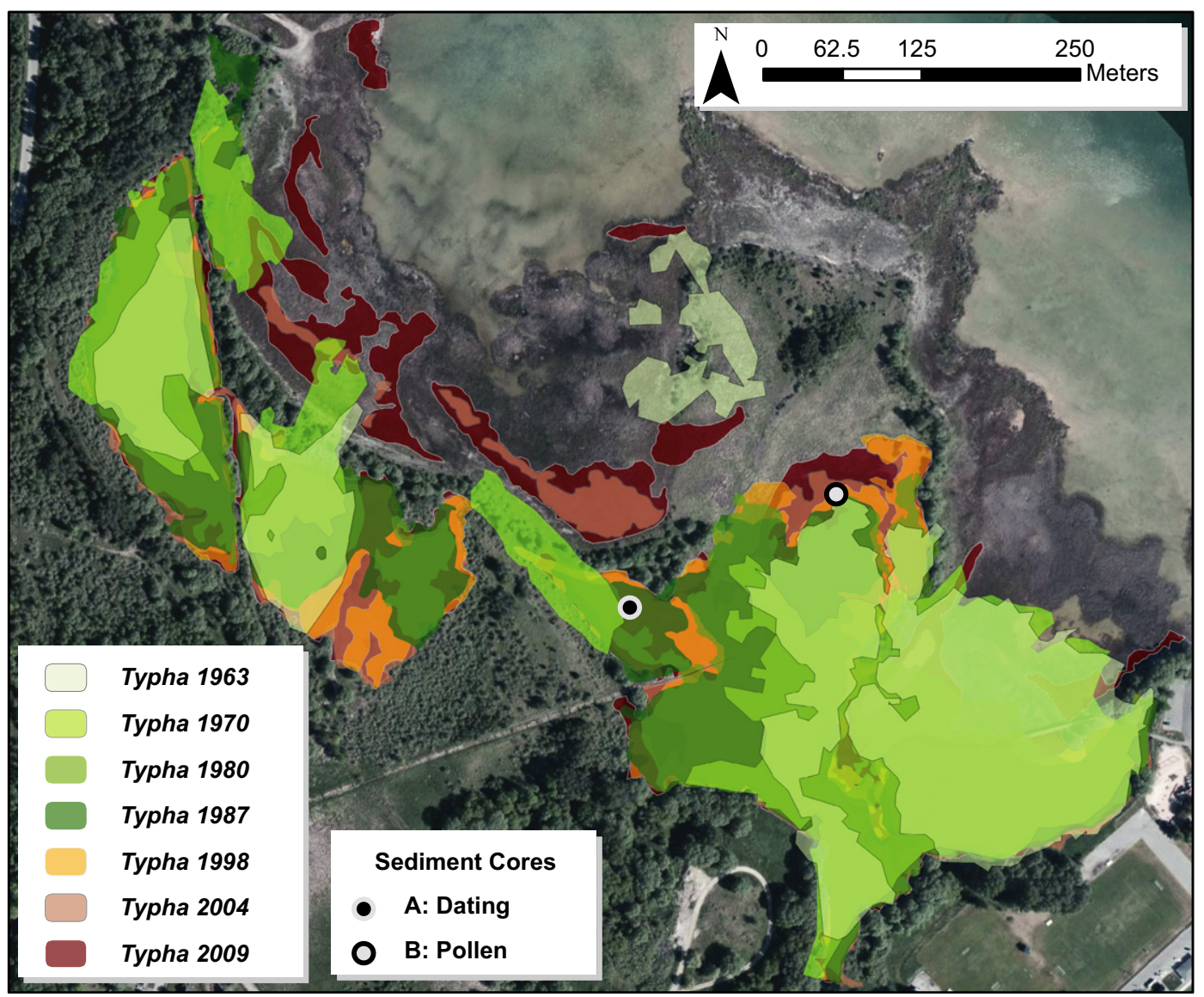

Figure 2 Map of the extent of Typha stands in Cheboygan Marsh, Michigan between 1963 and 2009. The locations where core samples were collected for sediment dating and pollen analyses are indicated. 


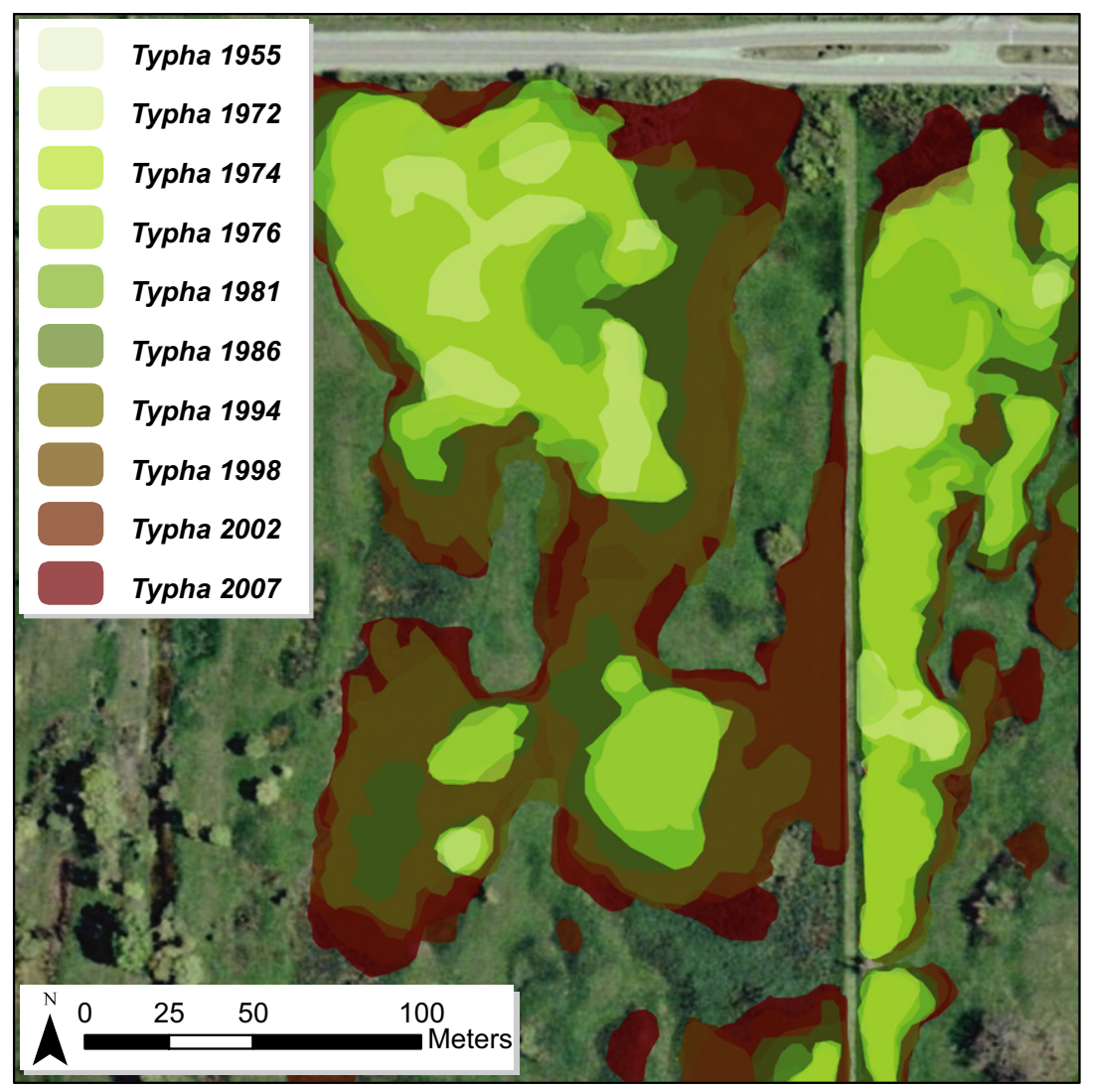

Figure 3 Map of a subset of aged Typha stands within Illinois Beach State Park, Illinois.

In Cheboygan Marsh, Typha was well established by 1963, the first year where high-quality aerial photography was available. In 1963, Typha dominated 8.2 ha of the marsh (35\% of area; Tables 1 and 2); between 1963 and 2009, marsh coverage expanded linearly at an annual rate of 0.14 ha year ${ }^{-1}$, dominating 14.6 ha $(62 \%$ of marsh area) by 2009 (Tables 1 and 2; Fig. 2).

Within the Illinois Beach wetland complex, Typha was first identifiable in 1955 in the Illinois Beach State Park (IBSP;
Fig. 3), aerial coverage increased through time and came to dominate 28.9 of 73 ha of habitat (40\% of wetland) by 2009 (Tables 1 and 3). In the Chiwaukee Prairie (CP) portion of the complex, a small patch of Typha ( $0.21 \mathrm{ha}$ ) was identified in 1963, also spread through time eventually dominating 2.7 of 53 ha $(5 \%)$ of habitat by 2009. In Spring Bluff natural area (SB), large stands of Typha (10.8 ha) were first identified on aerial imagery in 1974, spread through time eventually dominating 38.6 ha $(65 \%$ of wetland habitat; Tables 1

Table 1 Typha spp. dominance in each of four wetlands at the date of the earliest and most recent aerial image analysed and the average annual increase in Typha area over the study period

\begin{tabular}{|c|c|c|c|c|c|c|c|c|}
\hline \multirow{3}{*}{$\begin{array}{l}\text { Wetland area (ha) } \\
\text { Year }\end{array}$} & \multicolumn{2}{|c|}{ Cheboygan Marsh* } & \multicolumn{2}{|c|}{ Chiwaukee Prairie ${ }^{\dagger}$} & \multicolumn{2}{|c|}{ Illinois Beach State Park } & \multicolumn{2}{|c|}{$\begin{array}{l}\text { Spring Bluff } \\
\text { Natural Area }\end{array}$} \\
\hline & 23.2 & & $53.9^{\pi}$ & & 72.8 & & $59.5^{\pi}$ & \\
\hline & 1963 & 2009 & 1976 & 2009 & 1955 & 2007 & 1974 & 2007 \\
\hline Typha area (ha) & 8.21 & 14.60 & 0.21 & 2.71 & 3.2 & 28.85 & 10.78 & 38.57 \\
\hline Per cent of wetland & 35.4 & 62.4 & 0.4 & 5.0 & 4.5 & 39.6 & 18.1 & 64.8 \\
\hline $\begin{array}{l}\text { Average annual } \\
\text { increase (ha) }\end{array}$ & 0.14 & & 0.08 & & 0.4 & & 0.84 & \\
\hline
\end{tabular}

*Photo dates analysed: 1963, 1970, 1980, 1987, 1998, 2004, 2009.

†Photo dates analysed: 1976, 1981, 1986, 1995, 2000, 2005, 2009.

"Photo dates analysed: 1955, 1972, 1974, 1976, 1981, 1986, 1994, 1998, 2002, 2007.

\$Photo dates analysed: 1974, 1976, 1981, 1986, 1988, 2000, 2002, 2004, 2005, 2006, 2007.

"Determined from National Land Cover Dataset 2001 (NLCD 2001), aerial photo-interpretation, and field assessment.

**Represents the extent of aerial photography interpretation, not the entire property. 
Table 2 Results of aerial photography interpretation of Typha coverage and Typha pollen dominance by year in Cheboygan Marsh

\begin{tabular}{|c|c|c|c|c|c|}
\hline \multirow[b]{2}{*}{ Year } & \multicolumn{3}{|c|}{ Typha aerial coverage } & \multicolumn{2}{|l|}{ Typha pollen } \\
\hline & Area (ha) & Per cent of marsh* & Rate of increase (ha year $\left.{ }^{-1}\right)^{\dagger}$ & (Per cent of total) & (grains $\mathrm{ml}^{-1}$ sediment) \\
\hline 2009 & 14.60 & 63.0 & 0.62 & - & - \\
\hline 2004 & 11.48 & 49.5 & 0.12 & - & - \\
\hline 1998 & 10.74 & 46.3 & 0.10 & $95.6^{*}$ & $537^{*}$ \\
\hline 1987 & 9.63 & 41.5 & -0.02 & $87.9^{*}$ & $254^{*}$ \\
\hline 1980 & 9.79 & 42.2 & 0.05 & 90.3 & 239 \\
\hline 1970 & 9.28 & 40.0 & 0.15 & 85.0 & 116 \\
\hline 1963 & 8.22 & 35.4 & - & $74.1^{\dagger}$ & $48^{*}$ \\
\hline
\end{tabular}

*Marsh extent varied with fluctuating Lake Huron water levels. Per cent of marsh is a measure of the 2009 marsh area.

${ }^{\dagger}$ Average spread rate between aerial photo-interpreted years: (year 2 area-year 1 area)/(year 2 date-year 1 date).

*When pollen strata dates did not correspond directly with aerial photo dates, pollen data were averaged from the two years straddling the year of photo-interpretation ( \pm 3 years).

Table 3 Results of aerial photography interpretation of Typha coverage by year in Illinois Beach State Park, Chiwaukee Prairie and Spring Bluff wetlands

\begin{tabular}{|c|c|c|c|c|c|c|c|c|c|}
\hline \multirow[b]{2}{*}{ Year } & \multicolumn{3}{|l|}{ IBSP } & \multicolumn{3}{|l|}{$\mathrm{CP}$} & \multicolumn{3}{|l|}{ SB } \\
\hline & ha & $\% *$ & ha year ${ }^{-1 \dagger}$ & ha & $\% *$ & ha year ${ }^{-1 \dagger}$ & ha & $\% *$ & ha year ${ }^{-1 \dagger}$ \\
\hline 2009 & - & - & - & 2.71 & 5.0 & 0.28 & - & - & - \\
\hline 2007 & 28.8 & 39.6 & 0.52 & - & - & - & 38.6 & 64.8 & 0.11 \\
\hline 2006 & - & - & - & - & - & - & 38.5 & 64.6 & -1.21 \\
\hline 2005 & - & - & - & 1.57 & 2.9 & 0.02 & 39.7 & 66.7 & 0.63 \\
\hline 2004 & - & - & - & - & - & - & 39.0 & 65.6 & 0.86 \\
\hline 2002 & 26.3 & 36.1 & 1.95 & - & - & - & 37.3 & 62.7 & -0.34 \\
\hline 2000 & - & - & - & 1.43 & 2.7 & 0.06 & 38.0 & 63.9 & 1.33 \\
\hline 1998 & 18.5 & 25.3 & 0.42 & - & - & - & - & - & - \\
\hline 1995 & - & - & - & 1.16 & 2.1 & 0.04 & - & - & - \\
\hline 1994 & 16.8 & 23.0 & 0.14 & - & - & - & - & - & - \\
\hline 1988 & - & - & - & - & - & - & 22.0 & 37.0 & 1.26 \\
\hline 1986 & 15.7 & 21.4 & 1.57 & 0.76 & 1.4 & 0.09 & 19.5 & 32.7 & 2.11 \\
\hline 1981 & 7.8 & 10.7 & 1.15 & 0.28 & 0.5 & 0.01 & 8.9 & 15.0 & -1.00 \\
\hline 1980 & - & - & - & - & - & - & - & - & - \\
\hline 1976 & - & - & - & 0.21 & 0.4 & - & 13.9 & 23.3 & 1.55 \\
\hline 1974 & 11.4 & 15.7 & 1.47 & - & - & - & 10.8 & 18.1 & - \\
\hline 1972 & 8.5 & 11.7 & 0.31 & - & - & - & - & - & - \\
\hline 1955 & 3.3 & 4.5 & - & - & - & - & - & - & - \\
\hline
\end{tabular}

*Per cent of the wetland area evaluated.

${ }^{\dagger}$ Spread rate between aerial photo-interpreted years: (area 2 - area 1)/(year 2 - year 1 ).

and 3). By 1986, Typha had replaced all of the native vegetation in some Illinois Beach swales and by 2007 only pockets of native plant communities remained un-invaded throughout much of the complex (Fig. 3).

\section{Pollen analyses}

A significant linear relationship between unsupported ${ }^{210} \mathrm{~Pb}$ and sediment depth was observed (unsupported ${ }^{210} \mathrm{~Pb} \sim$ sediment depth $(\mathrm{cm}) ; R^{2}=0.890 ; F=24.32 ; P=0.016$; Table 4). Assuming a constant flux, constant sedimentation model (Robbins, 1978), we determined the rate of sediment deposi- tion in Cheboygan Marsh to be $0.4 \mathrm{~cm}_{\text {year }}{ }^{-1}$ through $24 \mathrm{~cm}$ of core length. The deposition rate was corroborated by ${ }^{137} \mathrm{Cs}$ data which peaked in the sediment profile at approximately $17 \mathrm{~cm}$, indicating an age of AD $1963 \pm 2$ years (Ritchie \& McHenry, 1990).

Typha pollen increased rapidly in relative abundance (\% of total pollen grains) between 1945 and 1955, when Typha becoming the majority pollen type in Cheboygan Marsh (Fig. 4). Typha dyads and triads, indicative of $T . \times$ glauca (Finkelstein, 2003; Table 5), first appeared in 1948 indicating an approximate date of $T . \times$ glauca establishment. Relative abundance of Typha pollen increased linearly between 1955 


\section{S. C. Lishawa et al.}

Table 4 Sediment core depth, total ${ }^{210} \mathrm{~Pb}$, unsupported ${ }^{210} \mathrm{~Pb},{ }^{137} \mathrm{Cs}$ and modelled age/year

\begin{tabular}{|c|c|c|c|c|c|c|}
\hline $\begin{array}{l}\text { Sediment depth } \\
(\mathrm{cm})\end{array}$ & $\begin{array}{l}\text { Core mid-point depth } \\
(\mathrm{cm})\end{array}$ & $\begin{array}{l}\text { Total }{ }^{210} \mathrm{~Pb}\left(\mathrm{dpm} \mathrm{g}^{-1}\right) \\
(\mathrm{SD})\end{array}$ & $\begin{array}{l}\text { Unsupported }{ }^{210} \mathrm{~Pb} \\
\left(\mathrm{dpm} \mathrm{g} \mathrm{g}^{-1}\right)\end{array}$ & $\begin{array}{l}{ }^{137} \mathrm{Cs}\left(\mathrm{dpm} \mathrm{g}^{-1}\right) \\
(\mathrm{SD})\end{array}$ & $\begin{array}{l}\text { Apparent } \\
\text { age }\end{array}$ & $\begin{array}{l}\text { Estimated } \\
\text { year* }\end{array}$ \\
\hline $0-8$ & 4 & $21.32(0.68)$ & 20.69 & $2.17(0.15)$ & 9.90 & 1996 \\
\hline $8-12$ & 10 & $12.06(0.60)$ & 11.39 & $3.59(0.16)$ & 24.75 & 1981 \\
\hline $12-16$ & 14 & $11.28(0.37)$ & 10.34 & $7.16(0.15)$ & 34.65 & 1971 \\
\hline $16-20$ & 18 & $10.96(0.59)$ & 9.95 & $6.95(0.23)$ & 44.55 & 1961 \\
\hline $20-24$ & 22 & $3.94(0.43)$ & 3.32 & $4.09(0.13)$ & 54.46 & 1952 \\
\hline $24-30$ & 26 & - & - & - & - & - \\
\hline
\end{tabular}

*Assuming a linear sediment deposition rate within each subsection, homogenized cores ${ }^{210} \mathrm{~Pb}$ and ${ }^{137} \mathrm{Cs}$ values correspond with core depth midpoint.
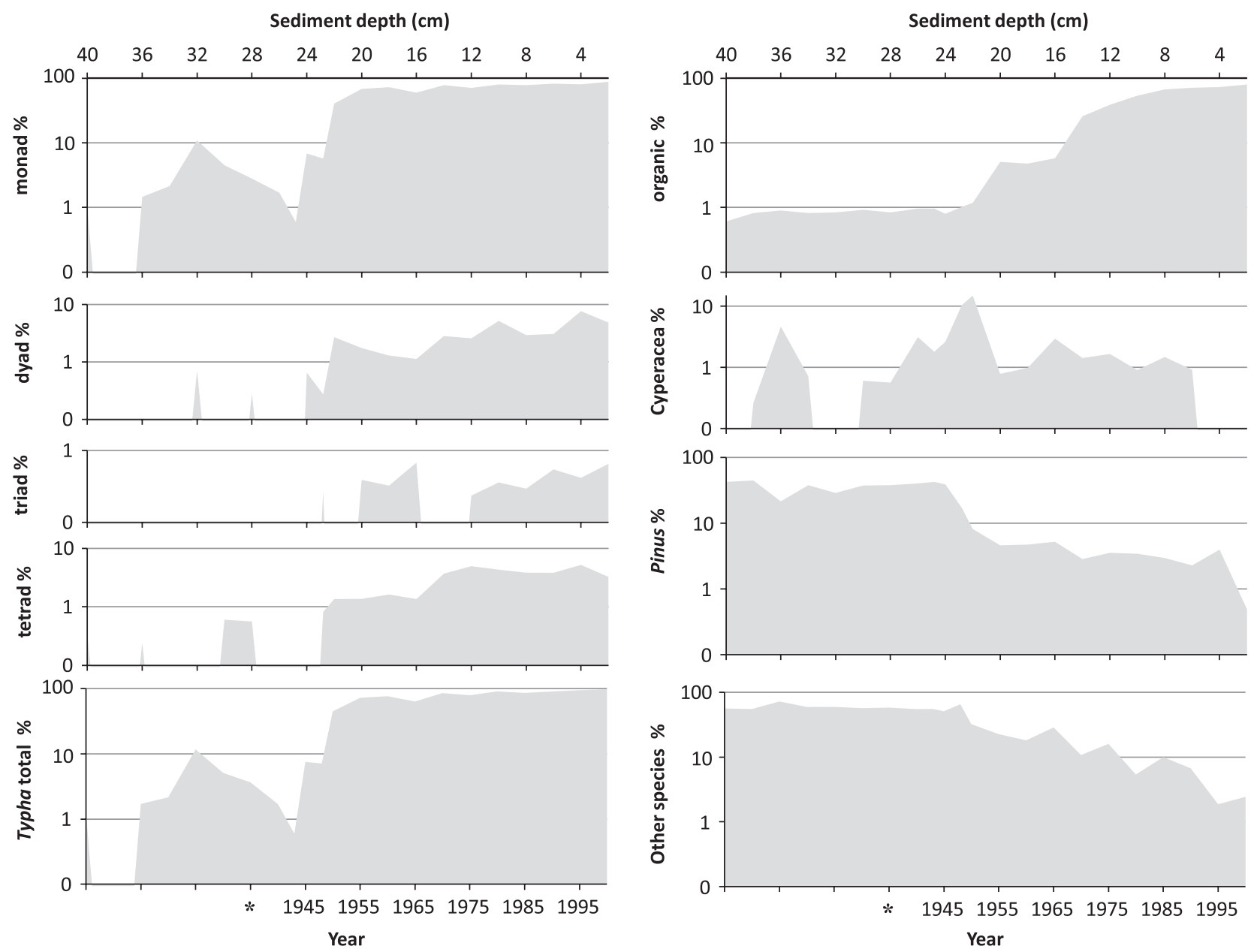

Figure 4 Percentage pollen and organic carbon derived from Cheboygan Marsh sediment cores. Dates were assigned based on ${ }^{210} \mathrm{~Pb}$ and ${ }^{137} \mathrm{Cs}$ sediment analyses; analyses were limited to the top $24 \mathrm{~cm}(1945-2000)$.

and 2000 (Fig. 4; see Table S1 in Supporting Information). Relative abundance of Cyperaceae pollen and concentration (grains per ml sediment) peaked in 1950, declined in the late 1950s, and disappeared from the record in the mid-1990s (Fig. 4; see Table S1). The initial increase in Typha abundance, concurrent with the brief ( 5 year) increase in Cyperaceae pollen, corresponded with a period of declining Lake Huron water levels; after peaking in 1952, water levels stea- dily declined through 1965, when water levels reached an 85-year low (USACE, 2010).

The relative per cent abundances of Typha pollen types for the full core are between the diagnostic ranges for $T . \times$ glauca and T. angustifolia (from Finkelstein, 2003), indicating the presence of both species within the wetland over the last 65 years (Table 5). Between 1945 and 2000, the estimated per cent abundance of $T . \times$ glauca pollen increased from 
Table 5 Per cent abundance of Typha monads, dyads, triads and tetrads averaged from the full pollen core, compared to documented values for pure Typha $\times$ glauca (Godr.) and T. angustifolia (L.) pollen, from Finkelstein (2003)

\begin{tabular}{lccl}
\hline & \multicolumn{2}{c}{$\%$ abundance: minimum-maximum (mean) } \\
\cline { 2 - 4 } & This study & \multicolumn{2}{c}{ Finkelstein (2003) } \\
\cline { 2 - 4 } & Per cent of Typha* & T. $\times$ glauca & T. angustifolia \\
\hline Monads & $88-97(89.8)$ & $47-92(75)$ & $96.5-100(99)$ \\
Dyads & $1-7(5.3)$ & $7-30(17)$ & $0-3(1)$ \\
Triads & $0-1(0.8)$ & $0-10(3)$ & $0(0)$ \\
Tetrads & $1-5(4.2)$ & $0-14(5)$ & $0-0.1(0.01)$ \\
\hline
\end{tabular}

*Per cent abundance of Typha spp. pollen.

$3.3 \%( \pm 5)$ to a maximum of $40.5 \%( \pm 5)$ in 1995 , indicating a substantial increase in wetland dominance (see Table S1). Prior to 1945 , Typha pollen averaged $98.2 \%$ monad and tetrad types, indicating nearly pure T. angustifolia and T. latifolia dominance (Finkelstein, 2003). Finally, we found a significant positive correlation between relative abundance of Typha pollen and sediment organic-matter content (Typha pollen abundance $\% \sim$ sediment organic matter $\%$; $F=13.321$; $P<0.01)$.

\section{Pollen core and aerial photography correlations}

A significant positive correlation between Typha marsh coverage and Typha pollen relative abundance was observed from Cheboygan marsh between 1963, the first year of photo-interpretation, and 1998 (Cheboygan Marsh Typha cover (ha) $\sim$ Typha pollen relative abundance; $F=47.82$; $P<0.01$; Fig. 5a). Using the GLM function, we modelled the marsh area dominated by Typha in the years between 1945 and 1963, the year with the first usable aerial image, and modelled marsh coverage values for the years intervening those with aerial photo-interpretation values (Fig. 5b).

\section{DISCUSSION}

We recreated the spread of a dominant invasive macrophyte, Typha, through time in two Great Lakes coastal wetlands using historical aerial photography, field demarcation and ancillary geospatial data. We generated invasion chronosequences of aged Typha stands in a GIS database. Stand-age maps will be used to assess the relationship between experimental Typha restoration outcomes and stand-age and have been used to evaluate effects of Typha residence time on a range of ecological conditions (Mitchell et al., 2011). The methods employed in this study allow for the spatial recreation of an invasion and should be replicable for other problematic invasive graminoid and forb species that grow in highly dominant stands and accumulate litter, such as Phragmites australis (Cav.) and Phalaris arundinacea (L.), which have both been successfully identified using remote sensing

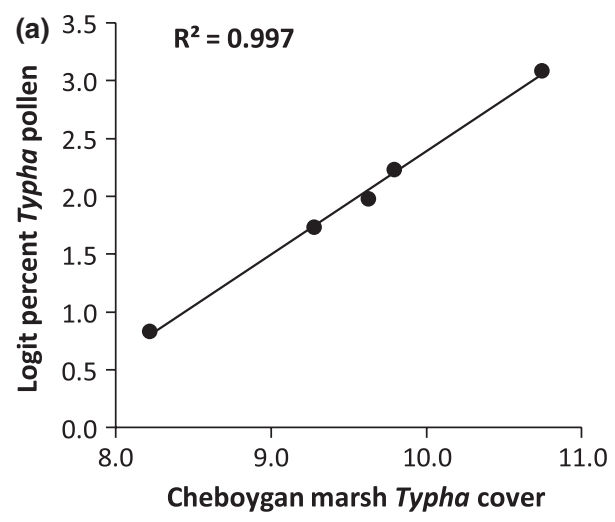

(ha)

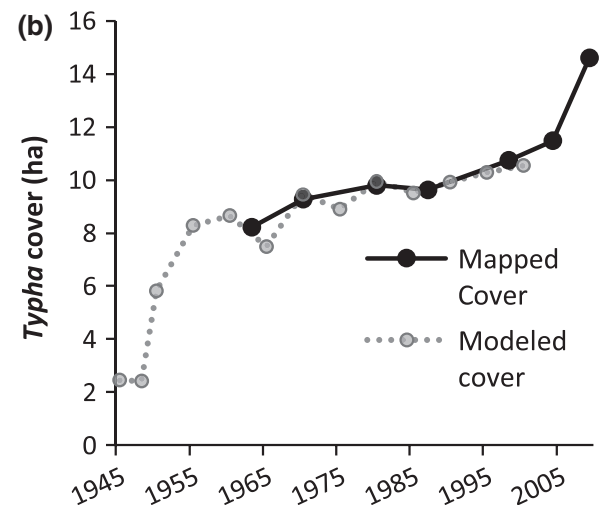

Figure 5 (a) Correlation between logit-transformed relative dominance of Typha pollen and Cheboygan Marsh Typha cover. (b) Typha cover (ha) between 1945 and 2009 illustrating aerial photo-mapped Typha cover (1963-2009) overlaid on generalized linear model modelled Typha cover (Cheboygan Marsh Typha cover (ha) Typha pollen dominance (\%); 1945-2000).

and aerial imagery interpretation (Rice et al., 2000; Jakubowski et al., 2010).

We employed a novel approach to analyse a species invasion by linking paleobotanical pollen analyses with historical mapping. A strong correlation between Typha dominance in the paleo-data and mapped cover data validate the accuracy of our historical mapping interpretations. Furthermore, we determined the date of historical invasion by $T . \times$ glauca . Additionally, the significant regression between Typha pollen dominance and wetland coverage allowed us to model the extent of Typha cover in Cheboygan Marsh from 1945 to 2009 at the temporal resolution of the pollen data and for 18 years prior to the first analysed aerial image (1963). Thus, linking the two data sets increased both the temporal scope and resolution of our historical understanding of Typha dominance in the study wetland. This study demonstrated the usefulness of paleoecological methods for investigating recent $(<100$ year) vegetation changes in wetland ecosystems, revealing aspects of the history and dynamics of a Typha invasion. For example, pollen analysis allowed us to distinguish the relative abundance of different Typha species, which is not possible solely using historical imagery. 
Pollen data provide insights into the historical invasion dynamics of two co-occurring invasive Typha spp. in a Great Lakes marsh. Typha angustifolia established early and rapidly, followed by a slower, linear increase in $T . \times$ glauca over the last 50 years. Prior to 1945, Typha pollen was dominated by T. angustifolia and T. latifolia. Following 1948, a mixture of $T . \times$ glauca and T. angustifolia pollen was present with T. $\times$ glauca pollen dominance increasing through time, revealing a successional trend between the two invasive Typha species (see Table S1). Additionally, a significant correlation between Typha pollen dominance and sediment organic-matter accumulation was observed, providing further support for the hypothesis that Typha may be a driver of ecological change in the wetlands it invades by fundamentally altering sediment conditions (Angeloni et al., 2006; Farrer \& Goldberg, 2009; Tuchman et al., 2009; Lishawa et al., 2010). However, only a single sediment core was analysed in this study, limiting the scope of interpretation.

In Cheboygan Marsh, Typha pollen became the majority pollen type in the 1950s, corresponding with a long-term decline in Lake Huron water levels (USACE, 2010). Varying water levels play an important role in the establishment and dominance of emergent macrophytes in the Great Lakes including Typha seedlings, which establish successfully on exposed mudflats (Keddy \& Reznicek, 1986; ter Heerdt \& Drost, 1994) and are often successful following high water or flooding periods (Miller, 1973; Farney \& Bookhout, 1982; Wilcox et al., 1985). Further research into the relationship between water levels and invasive species establishment is warranted in the light of predicted climate change driven Great Lakes water level declines (Mortsch \& Quinn, 1996; Lofgren et al., 2002; Angel \& Kunkel, 2009).

\section{Conclusions}

Determining whether invasive species are driving ecological degradation or are responding to degraded abiotic conditions remains an important question in the field of invasion ecology (Didham et al., 2005; MacDougall \& Turkington, 2005). Stand-age mosaic maps, like those created in this study, can allow researchers to evaluate biodiversity, abiotic conditions and assessment of ecological function along stand-age gradients, thereby shedding light on this question. For instance, Mitchell et al. (2011) found significant Typha stand-agedependent relationships in the biotic and abiotic ecosystem components: Typha density, litter mass, plant diversity and sediment organic matter. Mapping the spread of invasive plant species through time by interpretation of publically available historical aerial imagery in a GIS is a low-cost method which could greatly enhance invasion ecology research. The traditional aerial photography interpretation methods utilized in this study proved to be highly accurate for determining the extent of a dominant invasive macrophyte over the last 60 years.

Typha spp. are particularly suitable for wetland-scale paleo-analyses because of long-range wind-dispersal of pollen
(Janssen, 1984; Clark \& Patterson, 1985; Finkelstein \& Davis, 2005). However, pollen distribution distance is of critical importance when extrapolating vegetation cover relationships and should be considered when applying our techniques to other invasive species; additional pollen cores may be required to accurately determine wetland-scale dominance. Future studies examining invasive species pollen dominance at a range of distances from the source vegetation would yield important clarifying data.

Coupling historical photo-interpretation with an invaded site's pollen record is a novel approach to invasive species research. As we demonstrated, by correlating these two distinct historical data sets, researchers can generate invasive species cover models with longer historical perspective and higher temporal resolution than is possible using aerial imagery alone. This approach can provide a wealth of high-resolution data about relatively recent invasions by wetland macrophytes, improving understanding of invasion dynamics by enhancing the spatial and temporal scope of invasive species research.

\section{ACKNOWLEDGEMENTS}

This research was supported by a grant from the IllinoisIndiana Sea Grant College Program to N. Tuchman, D. Larkin, P. Geddes and D. Treering. We thank D. Larkin, P. Geddes, D. Maurer and B. Lawrence for their advice on various aspects of the research; M. Freyman, K. Jankowski, D. Miceli and M. Mitchell for assistance collecting data; and J. Wilson and three anonymous reviewers, whose comments greatly improved the manuscript.

\section{REFERENCES}

Albert, D.A., Wilcox, D.A., Ingram, J.W. \& Thompson, T.A. (2005) Hydrogeomorphic classification for Great Lakes coastal wetlands. Journal of Great Lakes Research, 31, 129-146. APHA (2005) Standard methods for the examination of water and wastewater, 21st edn. American Public Health Association, Washington, D.C.

Angel, J.R. \& Kunkel, K.E. (2009) The response of Great Lakes water levels to future climate scenarios with an emphasis on Lake Michigan-Huron. Journal of Great Lakes Research, 36, 51-58.

Angeloni, N.L., Jankowski, K.J., Tuchman, N.C. \& Kelly, J.J. (2006) Effects of an invasive cattail species (Typha $x$ glauca) on sediment nitrogen and microbial community composition in a freshwater wetland. F.E.M.S. Microbiology Letters, 263, 86-92.

Appleby, P.G. \& Oldfield, F. (1978) The calculation of ${ }^{210} \mathrm{~Pb}$ dates assuming a constant rate of supply of unsupported ${ }^{210} \mathrm{~Pb}$ to the sediment. Catena, 5, 1-8.

Blossey, B. (1999) Before, during and after: the need for long-term monitoring in invasive plant species management. Biological Invasions, 1, 301-311. 
Boers, A.M. \& Zedler, J.B. (2008) Stabilized water levels and Typha invasiveness. Wetlands, 28, 676-685.

Broström, A., Gaillard, M.J., Ihse, M. \& Odgaard, B. (1998) Pollen-landscape relationships in modern analogues of ancient cultural landscapes in southern Sweden - a first step towards quantification of vegetation openness in the past. Vegetation History and Archaeobotany, 7, 189-201.

Bunting, J.M., Duthie, H.C., Campbell, D.R., Warner, B.G. \& Turner, L.J. (1997) A palaeoecological record of recent environmental change at Big Creek Marsh, Long Point, Lake Erie. Journal of Great Lakes Research, 23, 349-368.

Callahan, J.T. (1984) Long-term ecological research. BioScience, 34, 363-367.

Carlsson, N.O.L., Jeschke, J.M., Holmqvist, N. \& Kindberg, J. (2010) Long-term data on invaders: when the fox is away, the mink will play. Biological Invasions, 12, 633-641.

Chun, Y.M. \& Choi, Y.D. (2009) Expansion of Phragmites australis (Cav.) Trin. ex Steud. (common reed) into Typha spp. (cattail) wetlands in northwestern Indiana, USA. Journal of Plant Biology, 52, 220-228.

Clark, J. \& Patterson, W. III (1985) The development of a tidal marsh: upland and oceanic influences. Ecological Monographs, 55, 189-217.

Crosbie, B. \& Chow-Fraser, P. (1999) Percentage land use in the watershed determines the water and sediment quality of 22 marshes in the Great Lakes basin. Canadian Journal of Fisheries and Aquatic Sciences, 56, 1781-1791.

Cwynar, L.C., Burden, E. \& McAndrews, J.H. (1979) An inexpensive sieving method for concentrating pollen and spores from fine-grained sediments. Canadian Journal of Earth Sciences, 16, 1115-1120.

Davis, C.B. \& Van der Valk, A.G. (1978) The decomposition of standing and fallen litter of Typha glauca and Scirpus fluviatilis. Canadian Journal of Botany, 56, 662-675.

Didham, R.K., Tylianakis, J.M., Hutchison, M.A., Ewers, R.M. \& Gemmell, N.J. (2005) Are invasive species the drivers of ecological change? Trends in Ecology \& Evolution, 20, 470-474.

Epstein, E., Spencer, E., Feldkirchner, D.C. \& Anderson, C. (2002) A Data Compilation and Assessment of Coastal Wetlands of Wisconsin's Great Lakes: Final Report: Natural Heritage Inventory Program, Bureau of Endangered Resources, Wisconsin Dept. of Natural Resources, Madison.

Fægri, K. \& Iversen, J. (1989) Finding the grain: Laboratory technique. Textbook of pollen analysis, 4th edn. (ed. by K. Fægri, P.E. Kaland and K. Krzywinski), pp. 69-89. Wiley, Chichester.

Farney, R.A. \& Bookhout, T.A. (1982) Vegetation changes in a Lake Erie marsh (Winous Point, Ottawa County, Ohio) during high water years. Ohio Journal of Science, 82, 103107.

Farrell, J.M., Murry, B.A., Leopold, D.J., Halpern, A., Rippke, M.B., Godwin, K.S. \& Hafner, S.D. (2010) Water-level regulation and coastal wetland vegetation in the upper St.
Lawrence River: inferences from historical aerial imagery, seed banks, and Typha dynamics. Hydrobiologia, 647, 127144.

Farrer, E.C. \& Goldberg, D.E. (2009) Litter drives ecosystem and plant community changes in cattail invasion. Ecological Applications, 19, 398-412.

Finkelstein, S.A. (2003) Identifying pollen grains of Typha latifolia, Typha angustifolia, and Typhax glauca. Botany, 81, 985-990.

Finkelstein, S.A. \& Davis, A.M. (2005) Modern pollen rain and diatom assemblages in a Lake Erie coastal marsh. Wetlands, 25, 551-563.

Finkelstein, S.A. \& Davis, A.M. (2006) Paleoenvironmental records of water level and climatic changes from the middle to late Holocene at a Lake Erie coastal wetland, Ontario, Canada. Quaternary Research, 65, 33-43.

Foster, B.L. \& Tilman, D. (2000) Dynamic and static views of succession: testing the descriptive power of the chronosequence approach. Plant Ecology, 146, 1-10.

Freyman, M. (2008) The effect of litter accumulation of the invasive cattail Typha x glauca on a great lakes coastal marsh. Masters Thesis, Loyola University Chicago, Chicago.

Frieswyk, C.B. \& Zedler, J.B. (2007) Vegetation change in great lakes coastal wetlands: deviation from the historical cycle. Journal of Great Lakes Research, 33, 366-380.

Galatowitsch, S.M., Anderson, N.O. \& Ascher, P.D. (1999) Invasiveness in wetland plants in temperate North America. Wetlands, 19, 733-755.

Goldberg, E.D. (1963) Geochronology with Pb-210. Radioactive dating, International Atomic Energy Agency Symposium Proceedings Vienna 1962, pp. 121-131. Vienna, Austria.

Harris, S.W. \& Marshall, W.H. (1963) Ecology of water-level manipulations on a northern marsh. Ecology, 44, 331-343.

He, K.S., Rocchini, D., Neteler, M. \& Nagendra, H. (2011) Benefits of hyperspectral remote sensing for tracking plant invasions. Diversity and Distributions, 17, 381-392.

ter Heerdt, G.N.J. \& Drost, H.J. (1994) Potential for the development of marsh vegetation from the seed bank after a drawdown. Biological Conservation, 67, 1-11.

Hestir, E.L., Khanna, S., Andrew, M.E., Santos, M.J., Viers, J.H., Greenberg, J.A., Rajapakse, S.S. \& Ustin, S.L. (2008) Identification of invasive vegetation using hyperspectral remote sensing in the California Delta ecosystem. Remote Sensing of Environment, 112, 4034-4047.

Hobbie, J.E., Carpenter, S.R., Grimm, N.B., Gosz, J.R. \& Seastedt, T.R. (2003) The US long term ecological research program. BioScience, 53, 21-32.

Huang, C. \& Asner, G.P. (2009) Applications of remote sensing to alien invasive plant studies. Sensors, 9, 4869-4889.

Jackson, S.T. (1997) Documenting natural and humancaused plant invasions using paleoecological methods assessment and management of plant invasions. Assessment and management of plant invasions (ed. by J.O. Luken and J.W. Thieret), pp. 37-55. Springer, New York. 
Jakubowski, A.R., Casler, M.D. \& Jackson, R.D. (2010) Landscape context predicts reed canarygrass invasion: implications for management. Wetlands, 30, 685-692.

Janssen, C.R. (1984) Modern pollen assemblages and vegetation in the Myrtle Lake Peatland, Minnesota. Ecological Monographs, 54, 213-252.

Jensen, J.R., Christensen, E.J. \& Sharitz, R. (1984) Nontidal wetland mapping in South Carolina using airborne multispectral scanner data. Remote Sensing of Environment, 16, 1-12.

Jensen, J.R., Hodgson, M.E., Christensen, E.J., Mackey, H.E., Tinney, L.R. \& Sharitz, R.R. (1986) Remote sensing inland wetlands: a multispectral approach. Photogrammetric Engineering Remote Sensing, 52, 87-100.

Keddy, P.A. \& Reznicek, A.A. (1986) Great Lakes vegetation dynamics: the role of fluctuating water levels and buried seeds. Journal of Great Lakes Research, 12, 25-36.

Larkin, D.J., Freyman, M.J., Lishawa, S.C., Geddes, P. \& Tuchman, N.C. (2012) Mechanisms of dominance by the invasive hybrid cattail Typha $\times$ glauca. Biological Invasions, 14, 65-77.

Lillesand, T.M., Kiefer, R.W. \& Chipman, J.W. (2008) Remote sensing and image interpretation, 6th edn. Wiley, New York.

Lishawa, S.L., Albert, D.A. \& Tuchman, N.C. (2010) Water level decline promotes Typha X glauca establishment and vegetation change in Great Lakes coastal wetlands. Wetlands, 30, 1085-1096.

Lockwood, J.L., Cassey, P. \& Blackburn, T. (2005) The role of propagule pressure in explaining species invasions. Trends in Ecology \& Evolution, 20, 223-228.

Lofgren, B.M., Quinn, F.H., Clites, A.H., Assel, R.A., Eberhardt, A.J. \& Luukkonen, C.L. (2002) Evaluation of potential impacts on Great Lakes water resources based on climate scenarios of two GCMs. Journal of Great Lakes Research, 28, 537-554.

Lovett, G.M., Canham, C.D., Arthur, M.A., Weathers, K.C. \& Fitzhugh, R.D. (2006) Forest ecosystem responses to exotic pests and pathogens in eastern North America. BioScience, 56, 395-405.

MacDougall, A.S. \& Turkington, R. (2005) Are invasive species the drivers or passengers of change in degraded ecosystems? Ecology, 86, 42-55.

Marchante, E., Kjøller, A., Struwe, S. \& Freitas, H. (2008) Short-and long-term impacts of Acacia longifolia invasion on the belowground processes of a Mediterranean coastal dune ecosystem. Applied Soil Ecology, 40, 210-217.

McDonald, M.E. (1955) Cause and effects of a die-off of emergent vegetation. Journal of Wildlife Management, 19, 24-35.

McLauchlan, K.K., Elmore, A.J., Oswald, W.W. \& Sugita, S. (2007) Detecting open vegetation in a forested landscape: pollen and remote sensing data from New England, USA. The Holocene, 17, 1233.

Meiners, S.J., Pickett, S.T.A. \& Cadenasso, M.L. (2001) Effects of plant invasions on the species richness of abandoned agricultural land. Ecography, 24, 633-644.
Meiners, S.J., Pickett, S.T.A. \& Cadenasso, M.L. (2002) Exotic plant invasions over 40 years of old field successions: community patterns and associations. Ecography, 25, 215-223.

Michigan State University (2008) Remote Sensing \& GIS Research and Outreach Services (RSeGIS) Aerial photography 1938, 1952, 1963. Available at: http://www.rsgis.msu. edu/aerial_archive/index.php (accessed 16 June 2008).

Miller, J.B. (1973) Vegetation changes in shallow marsh wetlands under improving moisture regime. Canadian Journal of Botany, 51, 1443-1457.

Mills, E.L., Leach, J.H., Carlton, J.T. \& Secor, C.L. (1993) Exotic species in the Great Lakes: a history of biotic crises and anthropogenic introductions. Journal of Great Lakes Research, 19, 1-54.

Mitchell, M.E., Lishawa, S.C., Geddes, P., Larkin, D.J., Treering, D. \& Tuchman, N.C. (2011) Time-dependent impacts of cattail invasion in a Great Lakes coastal wetland complex. Wetlands, 6, 1143-1149.

Moore, P.D. (1991) Pollen analysis, 2nd edn. Blackwell, Oxford.

Morrice, J.A., Danz, N.P., Regal, R.R., Kelly, J.R., Niemi, G. J., Reavie, E.D., Hollenhorst, T., Axler, R.P., Trebitz, A.S. \& Cotter, A.M. (2008) Human influences on water quality in Great Lakes coastal wetlands. Environmental Management, 41, 347-357.

Mortsch, L.D. \& Quinn, F.H. (1996) Climate change scenarios for Great Lakes Basin ecosystem studies. Limnology and Oceanography, 41, 903-911.

R Development Core Team (2010) R: a language and environment for statistical computing. R Foundation for Statistical Computing, Vienna, Austria. http://www.r-project.org (accessed 16 December 2010).

Rice, D., Rooth, J. \& Stevenson, J. (2000) Colonization and expansion of Phragmites australis in upper Chesapeake Bay tidal marshes. Wetlands, 20, 280-299.

Ritchie, J.C. \& McHenry, J.R. (1990) Application of radioactive fallout cesium-137 for measuring soil erosion and sediment accumulation rates and patterns: a review. Journal of Environmental Quality, 19, 215-233.

Robbins, J.A. (1978) Geochemical and geophysical applications of radioactive lead. The biogeochemistry of lead in the environment (ed. by J.O. Nriago), pp. 285-337. Elsevier, Amsterdam.

Robbins, B.D. (1997) Quantifying temporal change in seagrass areal coverage: the use of GIS and low resolution aerial photography. Aquatic Botany, 58, 259-267.

Shay, J.M. \& Shay, C.T. (1986) Prairie marshes in western Canada, with specific reference to the ecology of five emergent macrophytes. Canadian Journal of Botany, 64, 443-454.

Smith, S.G. (1987) Typha: Its taxonomy and the ecological significance of hybrids. Archiv für Hydrobiologie, 27, 129-138.

Snow, A.A., Travis, S.E., Wildova, R., Fér, T., Sweeney, P.M., Marburger, J.E., Windels, S., Kubatova, B., Goldberg, D.E. 
\& Mutegi, E. (2010) Species-specific SSR alleles for studies of hybrid cattails (Typha latifoliax T. angustifolia; Typhaceae) in North America. American Journal of Botany, 97, 2061-2067.

Springsteen, A., Loya, W., Liebig, M. \& Hendrickson, J. (2010) Soil carbon and nitrogen across a chronosequence of woody plant expansion in North Dakota. Plant and Soil, 328, 369-379.

Strayer, D.L., Eviner, V.T., Jeschke, J.M. \& Pace, M.L. (2006) Understanding the long-term effects of species invasions. Trends in Ecology \& Evolution, 21, 645-651.

Tchoukanski, I. (2008) ET Geowizard tool for ArcMap. www.ian-ko.com.

Travis, S.E., Marburger, J.E., Windels, S. \& Kubatova, B. (2010) Hybridization dynamics of invasive cattail (Typhaceae) stands in the Western Great Lakes Region of North America: a molecular analysis. Journal of Ecology, 98, 7-16.

Trebitz, A.S. \& Taylor, D.L. (2007) Exotic and invasive aquatic plants in Great Lakes coastal wetlands: distribution and relation to watershed land use and plant richness and cover. Journal of Great Lakes Research, 33, 705-721.

Trebitz, A.S., Brazner, J.C., Cotter, A.M., Knuth, M.L., Morrice, J.A., Peterson, G.S., Sierszen, M.E., Thompson, J.A. \& Kelly, J.R. (2007) Water quality in Great Lakes coastal wetlands: basin-wide patterns and responses to an anthropogenic disturbance gradient. Journal of Great Lakes Research, 33, 67-85.

Tuchman, N.C., Jankowski, K.J., Geddes, P., Wildova, R., Larkin, D.J. \& Goldberg, D.E. (2009) Patterns of environmental change associates with Typha X glauca invasion in a Great Lakes coastal wetland. Wetlands, 29, 964-975.

Tulbure, M.G., Johnston, C.A. \& Auger, D.L. (2007) Rapid invasion of a Great Lakes coastal wetland by non-native Phragmites australis and Typha. Journal of Great Lakes Research, 33, 269-279.

Underwood, E., Ustin, S. \& DiPietro, D. (2003) Mapping nonnative plants using hyperspectral imagery. Remote Sensing of Environment, 86, 150-161.

USACE (2010) Historic Great Lakes water level data (19182009). United States Army Corps of Engineers, Detroit. Available at: http://www.lre.usace.army.mil/greatlakes/hh/ (accessed 11 November 2010).

USDA (2009) Natural Resource Conservation Service, Farm Service Administration Aerial photography 2007-2009. United States Department of Agriculture, Washington. Available at: http://datagateway.nrcs.usda.gov/ (accessed 1 November 2010).

USGS (2009) Aerial photography 1939-2009. EarthExplorer. United States Geologic Survey, Washington. Available at: http://earthexplorer.usgs.gov/ (accessed 1 November 2010). USGS (2010) Aerial photography 1939-2010. Earth Resources Observation and Science Center. United States Geologic Survey, Washington. Available at: http://eros.usgs.gov/ (accessed 1 November 2010).
USNARA (2009) Aerial photography 1939-1986. Cartographic and Architectural Section. United States National Archives and Records Administration. Available at: http:// www.archives.gov/ (accessed 1 November 2010).

Vaccaro, L.E., Bedford, B.L. \& Johnston, C.A. (2009) Litter accumulation promotes dominance of invasive species of cattails (Typha spp.) in Lake Ontario wetlands. Wetlands, 29, 1036-1048.

Waters, I. \& Shay, J.M. (1990) A field study of the morphometric response of Typha glauca shoots to a water depth gradient. Canadian Journal of Botany, 68, 2339-2343.

Wilcox, D.A. \& Nichols, J. (2008) The effects of water-level fluctuations on vegetation in a Lake Huron wetland. Wetlands, 28, 487-501.

Wilcox, D.A., Apfelbaum, S.I. \& Hiebert, R.D. (1985) Cattail invasion of sedge meadows following hydrologic disturbance in the Cowles Bog wetland complex, Indiana Dunes National Lakeshore. Wetlands, 4, 115-128.

Wilcox, D.A., Kowalski, K.P., Hoare, H.L., Carlson, M.L. \& Morgan, H.N. (2008) Cattail invasion of sedge/grass meadows in Lake Ontario: photointerpretation analysis of sixteen wetlands over five decades. Journal of Great Lakes Research, 34, 301-323.

Williams, J.W. \& Jackson, S.T. (2003) Palynological and AVHRR observations of modern vegetational gradients in eastern North America. The Holocene, 13, 485-497.

Witkowski, E.T.F. \& Wilson, M. (2001) Changes in density, biomass, seed production and soil seed banks of the nonnative invasive plant, Chromolaena odorata, along a 15 year chronosequence. Plant Ecology, 152, 13-27.

Woo, I. \& Zedler, J.B. (2002) Can nutrients alone shift a sedge meadow towards dominance by the invasive Typha $\mathrm{x}$ glauca? Wetlands, 22, 509-521.

Zavaleta, E.S. \& Kettley, L.S. (2006) Ecosystem change along a woody invasion chronosequence in a California grassland. Journal of Arid Environments, 66, 290-306.

Zedler, J.B. \& Kercher, S. (2004) Causes and consequences of invasive plants in wetlands: opportunities, opportunists, and outcomes. Critical Reviews in Plant Sciences, 23, 431-452.

\section{SUPPORTING INFORMATION}

Additional Supporting Information may be found in the online version of this article:

Figure S1 Image illustrating Typha's unique spectral signature in an aerial photograph (USDA, 2009).

Table S1 Pollen counts and relative dominance (\% of total) by type per year interpreted.

As a service to our authors and readers, this journal provides supporting information supplied by the authors. Such materials are peer-reviewed and may be re-organized for online delivery, but are not copy-edited or typeset. Technical support issues arising from supporting information (other than missing files) should be addressed to the authors. 


\section{BIOSKETCHES}

Shane Lishawa is a Research Associate at the Center for Urban Environmental Research and Policy (CUERP), Loyola University Chicago. His research focuses on the interplay between invasive macrophytes, community dynamics, nutrient cycling and water level change in Laurentian Great Lakes coastal wetland ecosystems and explores the outcomes of ecological restoration treatments.

This work was a collaborative effort by the Illinois State Museum, where Eric Grimm is Curator and Chair of Bot- any, Nancy Tuchman's Aquatic Ecology Lab, and CUERP, where David Treering is a GIS Specialist, Lane Vail is a Research Associate and Owen McKenna was an Undergraduate Researcher.

Author contributions: N.T., L.V., and S.L. conceived the idea; E.G. provided palynological expertise; L.V., S.L., D.T. and O.M. collected data; and SL conducted the analyses and led the writing.

Editor: John Wilson 